\begin{tabular}{|c|c|c|c|}
\hline $\begin{array}{c}\text { A } \\
\text { REVIEW }\end{array}$ & $\begin{array}{r}\text { ADVANCE RESEARC } \\
\text { volume } 8 \mid \text { Issue }\end{array}$ & $\begin{array}{l}\text { OCIAL SCIENCE } \\
\text { 31-6418 }\end{array}$ & \\
\hline $0=$ & DOI: 10.15740/HAS/ARJSS/8.1/90-106 & Visit us : www.researchjournal.c & \\
\hline
\end{tabular}

\title{
A study on the doctrine of seperation of power of Montesquieu in reference to current plans and practices
}

Shriya Singh* and Mukund Sarda ${ }^{1}$

Department of Law, New Law College, Bharati Vidyapeeth (Deemed University), PUNE (M.S.) INDIA

${ }^{1}$ Faculty of Law, New Law College, Bharati Vidyapeeth (Deemed University), PUNE (M.S.) INDIA

\section{ARTICLE INFO :}

$\begin{array}{lll}\text { Received } & : & 04.03 .2017 \\ \text { Accepted } & : & 26.05 .2017\end{array}$

KEY WORDS :

Doctrine of seperation, Power of Montesquieu, Plans and practices

HOW TO CITE THIS ARTICLE : Singh, Shriya and Sarda, Mukund (2017). A study on the doctrine of seperation of power of Montesquieu in reference to current plans and practices. Adv. Res. $J$. Soc. Sci., 8 (1) : 90-106, DOI: 10.15740/ HAS/ARJSS/8.1/90-106.

*Author for correspondence

\begin{abstract}
This article is an attempt to study the doctrine of Separation Of Power as engraved in the Constitution of India and the difficulties faced by the three organs of the government while implementing and interpreting the provisions of the Constitution in letter and spirit. The research also draws a comparative approach with the UNITED STATES OF AMERICA's and UNITED KINGDOM's Constitutional scheme of Separation Of Powers. Throughout the course of research various cases have been discussed in which the Courts have recognized that there is no straightjacket formula to determine Separation Of Power. With the complexities in all the democracies in the world, overlapping of the jurisdiction is bound to arise. However, the three organs should keep a system of checks and balances so they do not end up violating the rights of the people. The Doctrine Separation Of Power is a part of the basic structure of the Indian Constitution. It is in this context, that the research was made on the 'Constitutional Plan and Practices with respect to Separation Of Power'.
\end{abstract}

